\title{
Increased input of circumpolar deep water-borne detritus to the glacial SE Atlantic Ocean
}

\author{
Germain Bayon \\ Southampton Oceanugraphy Centre, Southampton SO14 3ZH, United Kingulom \\ Noww at Département Géosciences Marines, IFREMER, 29280 Plonzané, France. (obbayon@iffemer.jr)
}

Christopher R. German and Robert W. Nesbitt

Southampton Octatography Centre, Southampton SO14.3ZH, United Kingtom

(cge@soc.soton.ac.uk; run2@soc.soton.ac.uk)

\section{Philippe Bertrand}

Département de Géologie et Oceunographte, UMR 5805 GNRS, Université de Bordeaux I, avenue des facultés, 33405 Talence Cedex, France (bertrand(ẹepor.u-bordeaux.fr)

\section{Ralph R. Schneider \\ Fachbereich Geowissenshaften, Universitaet Brenen, Klagenfinter S'trasse, 28359 Brethen, Germany (rscbneid@allgeo.uni-bremen.de)}

[1] Analysis of radiogenic isotopes in marine sediments can provide useful information on the provenance and transport of detrital material, directly relevant to palcoceanographic investigations. Here we show that the detrital Nd isotopic composition of recent SE Atlantic marine sediments matches the complex modernday hydrography. In these same cores, glacial-interglacial isotopic variations are consistent with previous investigations (using different paleoceanographic proxies), which have shown that the relative influence of North Atlantic Deep Water (NADW) into the South Atlantic was reduced during glacial periods. In a novel departure, however, we also calculate the mass accumulation rates of tenigenous material delivered by each of Circumpolar Deep Water (CDW) and NADW to demonstrate that the accumulation of detritus delivered by CDW was enhanced significantly in the glacial South Atlantic. This enhanced transport flux could be explained by an increased flow of CDW into the glacial South Allantic and/or an increased concentration of suspended terrigenous material transported by glacial CDW.

Components: 6241 words, 4 figures, 2 tables.

Keywords: Neodyminn isotopes; detribal fractions; Soutb Allantic; deep water circulation; IMAGES.

Index Terms: 3022 Marine Geology and Geoplysics: Marine sediments-processes and transport; 4267 Oceanography: General: Paleoceanography.

Received 30 April 2002; Revised 29 September 2002; Accepted 7 October 2002; Published 8 March 2003.

Bayon, G., C. R. Gernan, R. W. Nesthitt, P. Bertrand, and R. R. Schtuejder, Increased input of circumpolar cleep water-borne deirius to the glacial SE Allantic Ocean, Geochem. Geophlys. Geosyst., 4(3), 1025, doi:10.1029/2002GC000371, 2003. 


\section{Introduction}

[2] Thermohaline circulation plays a major role in climate change [Broecker and Denton, 1989]. At present, the formation of North Atlantic Deep Water feeds a 'global conveyor belt' which redistributes heat around the Earth. Atlantic deep-water progresses south toward the Southern Ocean, where it mixes with Circumpolar Deep Water and flows onward into the Indian and Pacific Oceans [Broecker, 1991]. The SE Atlantic Ocean, and the Cape Basin in particular, are therefore regions where fluctuations in the global influences of NADW and CDW can be monitored well [Charles and Fairbanks, 1992].

[3] Previously, various proxies have been used to investigate the general paltern of deep-water circulation during the last glacial maximum [Broecker and Denton, 1989; Charles and Fairbanks, 1992; Bickert and Wefer, 1996; Boyle and Rosenthal, 1996; Diecknann et al., 1996; Rutberg et al., 2000]. In the South Atlantic, however, the use of these proxies has led to conflicting results, indicating that additional tracers of deep-water circulation were needed. Records of $\delta^{13} \mathrm{C}$ [Charles and Fairbanks, 1992; Bickert and Wefer, 1999] and carbonate dissolution [Bickert and Wefer, 1996] have indicated that the chemical properties of glacial bottom-water in the South Allantic resembled contemporaneous deep-water in the Pacific Ocean, implying a strong reduction of the export of NADW to the glacial Southern Ocean. However, other proxies such as $\mathrm{Cd} / \mathrm{Ca}$ and $\mathrm{Ba} / \mathrm{Ca}$ records from benthic foraminifers have argued for the presence of a strong NADW component mixed into glacial southem water masses [Lea and Boyle, 1990; Boyle, 1992]. Similarly, sedimentary ${ }^{231} \mathrm{~Pa} /{ }^{230} \mathrm{Th}$ ratios measured in Atlantic sediments have suggested that the glacial analog of NADW continued to export vigorously to the Southern Ocean during the last glacial maxinum [Yu et al., 1996; Marchal et al., $2000]$. The divergence of these interpretations has been ascribed to problens related to (1) dissolution of carbonates $(\mathrm{Cd} / \mathrm{Ca} ; \mathrm{Ba} / \mathrm{Ca}$ [McCorkle, 1995]) and, (2) productivity effects, which may either overprint the "seawater signal" recorded in the shell of benthic foraminifers in high-productivity areas $\left(\delta^{13} \mathrm{C}\right.$ [Mackensen et al., 1993; Bickert. and Wefer, 1999]) or influence the scavenging rate of reactive particles; ${ }^{231} \mathrm{~Pa}{ }^{230} \mathrm{Th}$ [Marchal et al., 2000]). Recently, Rutberg et al. [2000] resolved part of this controversy by analyzing the $\mathrm{Nd}$ isotopic composition of the hydrogenous Fe-Mn oxide component in marine sediments; a new potential proxy which is not thought to be affected by productivity or dissolution effects. Their results, from the southern Cape Basin, provide a clear indication that the relative influence of NADW was markedly reduced in the Southern Ocean during the last glacial maximum. These Fe-Mn oxyhydroxide phases, just like most "traditional" paleoceanographic proxies (e.g., $\delta^{13} \mathrm{C}, \mathrm{Cl} / \mathrm{Ca}$ and $\mathrm{Ba} / \mathrm{Ca}$ ), act as direct archives of the chemical composition of past water masses. In the South Allantic and adjacent Southern Ocean, those tracers can provide information on the relative degree of mixing between Atlantic and southern water masses during the Late Quaternary. A proxy which would allow one to reconstruct the independent behavior of each of NADW and CDW, however, would offer an interesting complementary insight to our understanding of deep-water circulation in the glacial South Atlantic Ocean.

[4] In marine sediments, detrital clays and other silicate minerals retain their $\mathrm{Nd}$ isotopic signature during all of: continental weathering, sediment transport and diagenesis. Isotopic analyses of these terrigenous fractions, therefore, can provide direct and quantitative information on the provenance of the sediment under investigation [McCulloch and Wasserburg, 1978; Grousset et al., 1988; Jones et al., 1994; Revel et al., 1996; Innocent et al., 1997; Hernming et al., 1998; Asahara et al., 1999; Walter et al., 2000]. Measuring the $\mathrm{Nd}$ content and ${ }^{143} \mathrm{Nd} /{ }^{144} \mathrm{Nd}$ ratios of detrital fractions offers a further potential advantage over proxies which only record past seawater compositions: knowing the total accumulation mate of detrital sediment at any site one can, in principle, calculate the mass accumulation rate associated with each contributing detrital source. This, in turn, offers the potential to determine past variations associated with each transport mechanism, independently. 
[s] The transport of terrigenous particles to the deep-sea is controlled by a complex system of atmospheric, hydrographic, glacial and topographic conditions [Biscaye, 1965]. With increasing distance from source areas, advection of fine-grained particles by deep-water currents becomes the most important mode of detrital transport to deep-sea sediments [Biscaye, 1965; Petschick et al., 1996]. For example, studies in the North Atlantic area show clearly that the Nd isotopic composition of surface sediments matches the pathway of deep currents renarkably closely [Revel et al., 1996; Innocent et al., 1997]. In the deep South Atlantic, although surface currents have also been shown to influence the local isotopic composition of deepsea terrigenous sediments (i.e., in the southern Cape Basin [Rutberg et al., 2002]), fine-grained sediment transport and distribution remains primarily controlled by the deep-water advection of Circumpolar Deep Water and North Atlantic Deep Water [Dieckmann et al., 1996; Petschick et al., 1996; Gingele and Schmiedl, 1999; Walter et al., 2000; Kuhn and Dieckmann, 2002]. At present, they are three main potential sources of detritus to the deep southeast Atlantic ocean (Figure la): (1) clays delivered to the equatorial Atlantic by the Congo River and transported southward by NADW; (2) material from the southwestem Atlantic province advected northward by CDW; (3) aeolian dust blown from the Namib Desert by SE Trade winds [Petschick et al., 1996; Dieckmann et al., 1996]. Present-day sedimentation in the SE Atlantic is also strongly influenced by the presence of the Walvis Ridge, which almost completely prevents CDW from entering the Angola Basin (Figure 1b). In this study, we have analysed the Nd isotopic composition of detrital fractions from four sediment cores from the southeast Atlantic Ocean (NAUSICAA-IMAGES II cruise (Figure 1a)) to investigate variations in the accumulation of detritus transported by each of CDW and NADW to this region during the Lale Quaternary.

\section{Sampling and Methods}

[6] Two of our cores were raised from the northern Cape Basin (Figure 1a). These cores were chosen specifically to investigate the vertical structure of the deep SE Atlantic water column during the Late Quaternary: MD96-2086 (3606 m) was collected from the present-day boundary between NADW and Lower CDW while MD96$2098(2910 \mathrm{~m})$ was taken from nearer to the core of present-day NADW [Reid, 1989] (Figure 1b). We have also investigated the $\mathrm{Nd}$ isotopic composition of two further cores, MD96-2091 from the Angola Basin and MD96-2085 from the central Cape Basin, which lie north and south of the northern Cape Basin cores, along the southward flowing trajectory of modern-day NADW (Figure 1b).

[7] Apart from carbonate-rich core MD96-2085 $\left(>85 \% \mathrm{CaCO}_{3}[\mathrm{Bay}\right.$ on, 2002]), lithologies are variable down-core, exhibiting changes in the relative amounts of carbonate ooze, biogenic silica (mainly diatoms and sponge spicules), and the terrigenous fraction [Bertrand et al., 2002a, 2002b]. Lowering of sea level during glacial times might be expected to have exposed the Namibian continental shelf to erosion and potentially enhanced transport of detrital particles to the deep-sea. However, no evidence for turbidite or slump deposition is observed in any of the cores studied [Bertrand et al., 2002a] and clay mineral studies in other sediment cores studied from the same arca indicate that erosion of the shelf has not contributed significantly to base-of-slope sedimentation, even during periods of low sea level [Dieckmann et al, 1996; Gingete and Schmied, 1999].

[8] Detrital fractions were isolated according to the procedure described in Bayon et al. [2002], which involves the separation of carbonates, Fe-Mn oxyhydroxides and organic compounds from the detrital sediment phase. In this work, $\mathrm{Nd}$ isotopic compositions were determined for the entire detrital fraction rather than any specific grain-size fraction. In all sediments, this detritus comprised predominantly fine-grained material $(<0 \mu \mathrm{m})$ with glacial sediments containing an additional coarser: sand fraction (G. Bayon, unpublished data, 2002). An age model for core MD96-2091 (Angola Basin) has been established based on $\delta^{18} O$ analyses in bulk carbonate fractions. Age models for cores MD96-2086 [Bertrand et al., 2002a], -2085 [Chen 


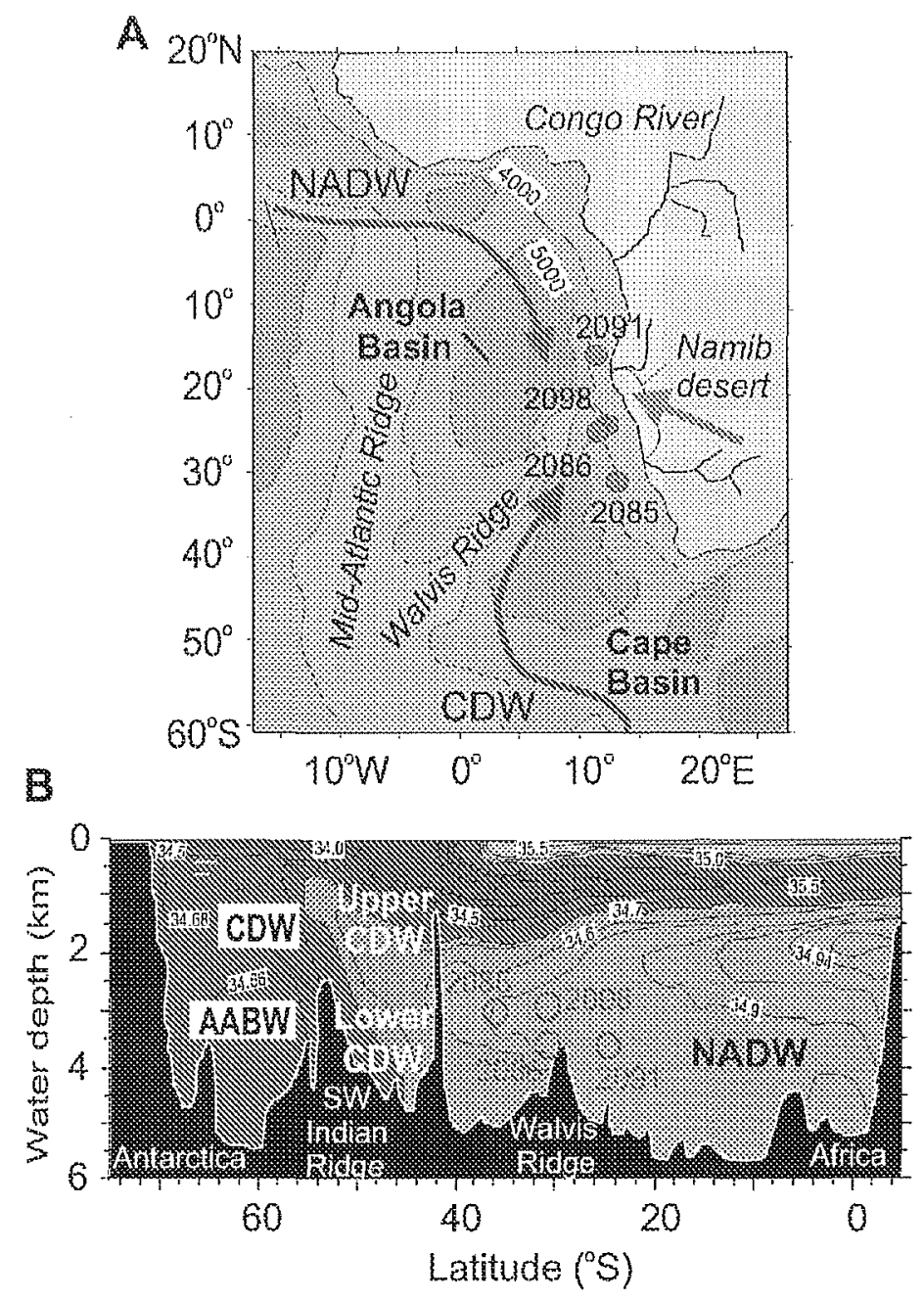

Figure 1. Map and N-S cross-section of our South East Atlantic study area. (a) Location map showing positions of core analyzed for this study. Cores MD96-2098 and -2086 were raised from the northern Cape Basin. Core MD962091 and -2085 were collected from further north and south, in the Angola Basin and central Cape Basin, respectively. NADW (red arrow) transports clays delivered to the Equatorial Atlantic by the Congo River; whereas advection of CDW (blue arrow) camies detritus from the SW Atlantic province. Southeasterly trade winds (orange arrow) deliver neolinn dusts from the Namib Desert. (b) Cross-section of salinity for the present-day Soulh East Atlantic Ocean along the Greenwich meridian (modilied from Reid [1989]). The depths and latitudes of the sediment cores analyzed in this study are represented schematically as red circles.

et al., 2002] and -2098 (R. Schneider, unpublished data, 1998) are derived from benthic foraminiferal $\delta^{18} \mathrm{O}$ stratigraphies. These stratigraphies were correlated to the $\delta^{18} \mathrm{O}$ reference curve of Martinson et al. [1987], assuming linear sedimentation rates between selected age conirol points. Accumulation rates of malerial from each of the three different detrital sources have been determined by combin- ing the percentage contribution from each source, calculated from $\mathrm{Nd}$ isotope data (see later), and with bulk accumulation rates for the total terrigenous fraction. Uncertainties in these absolute terrigenous accumulation rates, derived from $\delta^{18} \mathrm{O}$ stratigraphies depend upon the age difference between any two control points from which a linear sedimentation rate has been assumed. Those uncer- 
Table 1. No Isotope Data of Detrital Fractions and Terrigenous Accumulation Rates (MAR) ${ }^{\mathrm{n}}$

\begin{tabular}{|c|c|c|c|c|c|c|c|c|c|c|c|}
\hline \multirow[b]{2}{*}{$\begin{array}{c}\text { Deptl in Core, } \\
\mathrm{cm}\end{array}$} & \multirow[b]{2}{*}{$\begin{array}{l}\text { Age, } \\
\text { kyr }\end{array}$} & \multirow[b]{2}{*}{$\begin{array}{l}\text { Isotopic } \\
\text { Stage }\end{array}$} & \multirow[b]{2}{*}{$\varepsilon_{\text {Tid }}^{b}$} & \multirow[b]{2}{*}{$\begin{array}{l}{[\mathrm{Nd}]} \\
\text { ppin }\end{array}$} & \multicolumn{3}{|c|}{ Detrital sources, $\%$} & \multicolumn{3}{|c|}{ Terrigenons MIAR (g/cm2/kyr) } & \multirow[b]{2}{*}{$\begin{array}{l}\text { Ratio } \\
(2) /(1)\end{array}$} \\
\hline & & & & & $\begin{array}{l}\text { Namib } \\
\text { Winds }\end{array}$ & $\begin{array}{l}\text { Congo } \\
\text { River }\end{array}$ & $\begin{array}{c}\text { SW } \\
\text { Allantic }\end{array}$ & Total & $\begin{array}{l}\text { Congo, } \\
\text { source (1) }\end{array}$ & $\begin{array}{l}\text { SW Atlantic, } \\
\text { sourte (2) }\end{array}$ & \\
\hline \multicolumn{12}{|c|}{ MD96-2091 (Location: Angala Basin - $14^{\circ} 53^{\prime} \mathrm{s}, 10^{\circ} 23^{\prime} \mathrm{E}$, depth $=3569 \mathrm{~m}$ ) } \\
\hline 2 & 1.6 & Hol & $-21.89=0.12$ & 28.4 & 32 & 68 & 0 & - & - & - & - \\
\hline 21 & 7.2 & Hol & $-21.95 \div 0.14$ & 25.6 & 40 & 60 & 0 & 1.5 & 0.9 & 0 & 0 \\
\hline 41 & 9.6 & $\mathrm{rlol}$ & $-20.34 \pm 0.08$ & 22.5 & 53 & 47 & 0 & 3.8 & 1.8 & 0 & 0 \\
\hline 61 & 12.0 & $\mathrm{Hol} / 2$ & $-18.22 \pm 0.08$ & 23.6 & 53 & 44 & 4 & 3.6 & 1.6 & 0.1 & 0.08 \\
\hline 81 & 15.5 & 2 & $-18.08 \pm 0.08$ & 24.6 & 48 & 45 & 7 & 2.8 & 1.3 & 0.2 & 0.15 \\
\hline 121 & 24.7 & $2 / 3$ & $\ldots .6 .99 \pm 0.08$ & 21.9 & 57 & 36 & 7 & 2.3 & 0.8 & 0.2 & 0.19 \\
\hline 321 & 65.0 & 4 & $-16.97 \pm 0.08$ & 24.3 & 46 & 41 & 13 & 2.4 & 1.0 & 0.3 & 0.31 \\
\hline 341 & 68.8 & 4 & $-17.30 \pm 0.0 k$ & 21.5 & 59 & 36 & 4 & 2.8 & 1.0 & 0.1 & 0.12 \\
\hline 361 & 72.5 & $4 / 5$ & $-18.26 \pm 0.10$ & 22.4 & 58 & 41 & 0 & 2.7 & 1.1 & 0 & 0.01 \\
\hline 381 & 76.3 & 5 & $-18.61 \div 0.08$ & 23.7 & 54 & 45 & 1 & 2.3 & 1.0 & 0 & 0.03 \\
\hline 511 & 105.0 & 5 & $-18.43 \pm 0.08$ & 19.0 & 66 & 34 & 0 & 2.4 & 0.8 & 0 & 0 \\
\hline 611 & 117.7 & 5 & $-20.03=0.14$ & 26.5 & 44 & 56 & 0 & 4.0 & 2.2 & 0 & 0 \\
\hline 641 & 122.0 & 5.5 & $-20.01+0.12$ & 27.0 & 42 & 58 & 0 & 3.8 & 2.2 & 0 & 0 \\
\hline 651 & 126.8 & 5 & $\cdots 19.60=0.18$ & 27.2 & 42 & 57 & 2 & 1.1 & 0.6 & 0 & 0.03 \\
\hline 661 & 131.7 & 6 & $-19.59 \pm 0.10$ & 29.9 & 30 & 63 & 7 & 1.1 & 0.7 & 0.1 & 0.11 \\
\hline 681 & 141.3 & 6 & $-18.71 \pm 0.20$ & 24.2 & 52 & 47 & 2 & 1.1 & 0.5 & 0 & 0.04 \\
\hline 701 & 151.0 & 6 & $\cdots 18.69 \pm 0.14$ & 24.1 & 52 & 46 & 1 & 1.3 & 0.6 & 0 & 0.03 \\
\hline 761 & 166.0 & 6 & $-16.52 \pm 0.10$ & 23.2 & 49 & 37 & 14 & 1.9 & 0.7 & 0.3 & 0.37 \\
\hline 961 & 219.5 & 7 & $-18.34 \pm 0.10$ & 26.1 & 42 & 49 & 9 & 1.8 & 0.9 & 0.2 & 0.18 \\
\hline 1041 & 253.0 & 8 & $-19.27 \pm 0.08$ & 25.8 & 47 & 52 & 1 & 1.3 & 0.7 & 0.0 & 0.02 \\
\hline 1082 & 263.0 & 8 & $-17.22 \pm 0.08$ & 22.8 & 53 & 39 & 8 & 2.1 & 0.8 & 0.2 & 0.21 \\
\hline 1141 & 295.3 & 8 & $\cdots 18.65 \pm 0.10$ & 22.2 & 58 & 42 & 0 & 0.8 & 0.3 & 0 & 0 \\
\hline 1161 & 303.6 & $8 / 9$ & $-18.02 \pm 0.10$ & 24.1 & 50 & 44 & 6 & 0.8 & 0.3 & 0.0 & 0.14 \\
\hline 1201 & 320.2 & 9 & $-20.07 \pm 0.08$ & 26.7 & 43 & 57 & 0 & 1.1 & 0.6 & 0 & 0 \\
\hline \multicolumn{12}{|c|}{ MD96-2098 (Location: Northen Cape Basin $-25^{\circ} 36^{\prime} \mathrm{S}, 12^{\circ} 38^{\prime} E$, depth $=2910 \mathrm{~m}$ ) } \\
\hline 0 & 6.0 & Hol & $-12.95 \pm 0.21$ & 12.0 & 91. & 9 & 0 & - & - & - & - \\
\hline 25 & 7.0 & Hol & $-13.30 \pm 0.16$ & 16.2 & 75 & 17 & 9 & 3.4 & 0.6 & 0.3 & 0.52 \\
\hline 110 & 11.4 & $\mathrm{Hol} / 2$ & $-11.98 \div 0.16$ & - & - & - & - & - & - & - & - \\
\hline 171 & 14.4 & 2 & $-11.14 \pm 0.10$ & 14.5 & 80 & 10 & 11 & 5.3 & 0.5 & 0.6 & 1.12 \\
\hline 201 & 16.0 & 2 & $-10.53 \pm 0.16$ & 17.5 & 62 & 12 & 27 & 5.1 & 0.6 & 1.4 & 2.34 \\
\hline 231 & 17.6 & 2 & $-10.55 \pm 0.16$ & 17.3 & 63 & 11 & 26 & 5.3 & 0.6 & 1.4 & 2.29 \\
\hline \multicolumn{12}{|c|}{ MD9G-2086 (Locution: Northem Cape Basin - $25^{\circ} 49^{\prime} \mathrm{S}, 12^{\circ} \mathrm{g}^{\prime} \mathrm{E}$, depih $=3600 \mathrm{~m}$ ) } \\
\hline 46 & 0.4 & $\mathrm{Hol}$ & $-11.84 \pm 0.12$ & 20.6 & 48 & 19 & 33 & 1.0 & 0.2 & 0.3 & 1.79 \\
\hline 86 & 7.5 & $\mathrm{Hol}$ & $-11.33 \pm 0.12$ & 23.1 & 32 & 20 & 47 & 1.3 & 0.3 & 0.6 & 2.35 \\
\hline 121 & 10.6 & $1101 / 2$ & $-10.12 \pm 0.41$ & 26.0 & 12 & 19 & 69 & 2.4 & 0.5 & 1.6 & 3.60 \\
\hline 161 & 15.2 & 2 & $\ldots 9.87 \pm 0.16$ & 23.5 & 26 & 16 & 58 & 2.7 & 0.4 & 1.6 & 3.73 \\
\hline 469 & 48.3 & 3 & $-10.83 \div 0.10$ & 15.8 & 72 & 10 & 18 & 1.8 & 0.2 & 0.3 & 1.73 \\
\hline 609 & 62.2 & 4 & $-9.56 \pm 0.518$ & 17.9 & 57 & 3) & 34 & 3.8 & 4.4 & 1.3 & 3.54 \\
\hline 748 & 81.7 & 5 & $-10.85 \pm 0.08$ & 16.4 & 68 & 11 & 21 & 1.7 & 0.2 & 0.4 & 1.85 \\
\hline 962 & 122.0 & 5.5 & $-11.86+0.10$ & 18.1 & 62 & 16 & 23 & 0.5 & 0.1 & 0.1 & 1.47 \\
\hline 1009 & 126.1 & $5 / 6$ & $-\cdots 11.26 \pm 0.10$ & 16.3 & 70 & 12 & 18 & 2.9 & 0.3 & 0.5 & 1.51 \\
\hline 1072 & 131.0 & 6 & $--7.67 \pm 0.16$ & 10.5 & 97 & 0 & 4 & 2.1 & 0 & 0 & 0 \\
\hline 1421 & 181.6 & 6 & $-9.99 \pm 0.10$ & 20.4 & 44 & 13 & 43 & 3.7 & 4.5 & 1.4 & 3.08 \\
\hline $14 d 1$ & 184.7 & $6 / 7$ & $-10.05 \pm 0.18$ & 19.3 & 50) & 12 & 38 & 4.1 & 0.5 & 1.3 & 2.80 \\
\hline 1481 & 190.9 & 7 & $-10.87 \div 0.14$ & 18.1 & 59 & 13 & 28 & 3.7 & 0.5 & 0.8 & 1.74 \\
\hline 1501 & 193.1 & 7 & $-10.71 \div 0.10$ & -- & - & - & - & - & - & - & - \\
\hline 1516 & 195.5 & 7 & $-10.67 \pm 0.20$ & 16.4 & 68 & 11 & 21 & 0.4 & 0.0 & 0.1 & 1.37 \\
\hline \multicolumn{12}{|c|}{ MD96-2085 (Location: Cental Cape Basin $-29^{\circ} 42^{\prime} \mathrm{S}, 12^{\circ} .56^{\prime} \mathrm{L}$, depth $=3001 \mathrm{~m}$ ) } \\
\hline 0 & 0.5 & Hol & $--11.39 \pm 0.27$ & 21.6 & 41 & 19 & 41 & - & - & - & - \\
\hline 20 & 3.8 & Hol & $-10.90=1: 0.12$ & 26.1 & $1 \overline{5}$ & 22 & 63 & 0.4 & 0.1 & 0.2 & 2.88 \\
\hline 50 & 8.4 & $\mathrm{Hol}$ & $\ldots 11.59 \pm 0.14$ & 25.6 & 20 & 24 & 56 & 0.4 & 0.1 & 0.2 & 2.34 \\
\hline 60 & 10.0 & Hol & $-10.92 \div 0.14$ & 21.5 & 40 & 17 & 43 & 0.4 & 0.1 & 0.2 & 2.52 \\
\hline 90 & 14.6 & 2 & $-10.85 \pm 0.18$ & 26.9 & 10 & 23 & 67 & 0.5 & 4].1. & 0.3 & 2.96 \\
\hline 110 & 18.8 & 2 & $-9.79 \pm 0.12$ & 21.5 & 37 & 14 & 50 & 0.5 & 0.1 & 0.3 & 3.67 \\
\hline
\end{tabular}

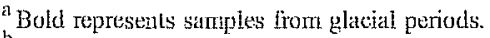

${ }^{b}$ Errots given are in-tun enors $(2$ s.e). Note that these are generally lower that the external reproducibility (2 s.d. $= \pm 0.16 \varepsilon$ units). 
A

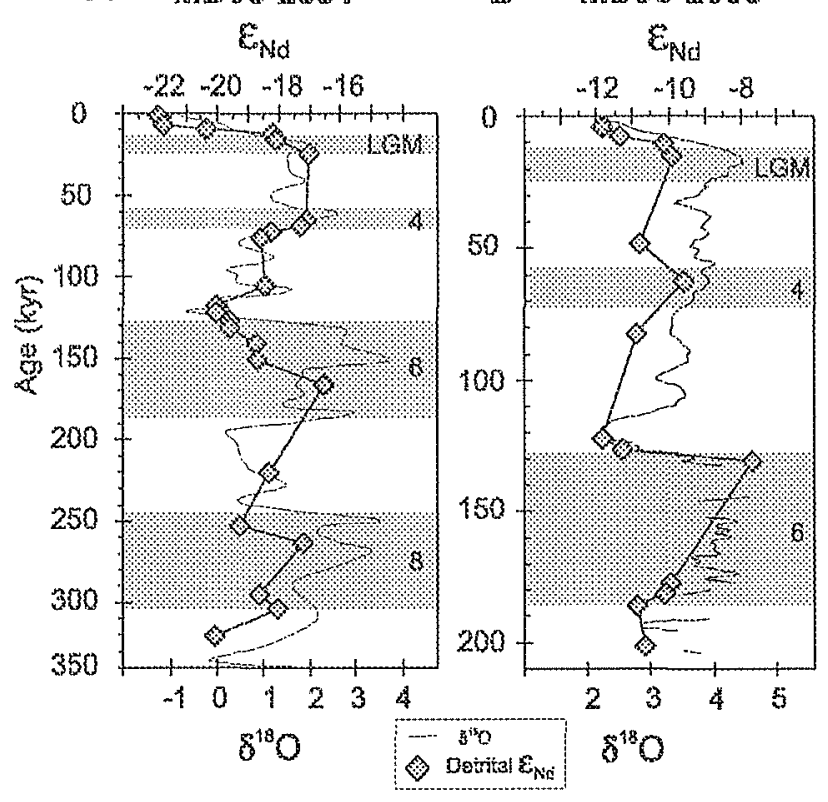

Figure 2. Nd isotopic compositions of detrital fractions and $\delta^{18} \mathrm{O}$ record versus age (left side) and marine isotope stages (right side). Nd isotope data follow the $\delta^{18} \mathrm{O}$ climatic signal, with terrigenous fractions from both (a) $\mathrm{MD} 96-$ 2091 and (b) -2086 cores showing a trend toward more radiogenic $\varepsilon_{N d}$ values in glacial versus interglacial periods. Cores -2098 and -2085 also exhibits a similar trend (Table 1 ).

tainties can be important in our study (i.e., from $\pm \mathrm{ca} .5 \%$ for the longest episodes to $\pm c a .75 \%$ for the shortest ones [Bertrand et al., 2002a]).

[9] Nd concentrations were analysed by ICP-MS on a VG Plasmaquad $\mathrm{II}+$ instrument with an external accuracy of $5 \%(2$ s.d.) and an internal precision better than 3\% (2 s.e.). For isotopic analyses, Nd was separated by standard chromatographic methods and ${ }^{143} \mathrm{Nd} /{ }^{144} \mathrm{Nd}$ ratios were determined using dynamic mode data collection on a VG Sector 54 thermal ionization mass spectromeler. Isotope ratios were normalized to ${ }^{146} \mathrm{Nd} /{ }^{144} \mathrm{Nd}=0.7219$. Analysis of the Nd-standard Ndi-1 gave ${ }^{143} \mathrm{Nd} /{ }^{144} \mathrm{Nd}=0.512108 \pm 8(2 \mathrm{~s} . \mathrm{d} ., \mathrm{n}$ $=14$ ), during the run period ( 3 months).

\section{Results and Discussion}

[in] In cores MD96-2091 (Angola basin) and MD96-2086 (northern Cape Basin), the Nd isotopic compositions of the detrital fractions follow the $8^{18} \mathrm{O}$ climatic signal (Table 1; Figure 2 ) with terri- genous fractions of both cores exhibiting more radiogenic (higher) $\varepsilon_{\mathrm{Nd}}$ values during glacials than interglacials. The two other cores from the northern (MD96-2098) and central (MD96-2085) Cape Basin also exhibit a trend toward more radiogenic $\varepsilon_{\text {Nd }}$ values from the Holocene to the LGM (Table 1).

\section{1. $\varepsilon_{\mathrm{Nd}}$ Values of Recent Clay-Rich Fractions: A Record of Present-Day Hydrography}

[11] In Figure $3 a$, $\varepsilon_{\mathrm{Nd}}$ data are plotted against $1 / \mathrm{Nd}$ concentrations to investigate whether the $\mathrm{Nd}$ isotopic composition of recent (interglacial) detrital fractions accurately record the present-day hydrography of the deep southeast Atlantic. All $\mathrm{Nd}$ isotopic compositions and concentrations for the end-members are based on data from the literature or from this study. Nd concentrations and isotopic compositions of the three detrital end-members are given in Table 2. The source of sediment in the Angola Basin (core MD96-2091) is clearly dominated $(>50 \%)$ by highly unradiogenic Congo River 


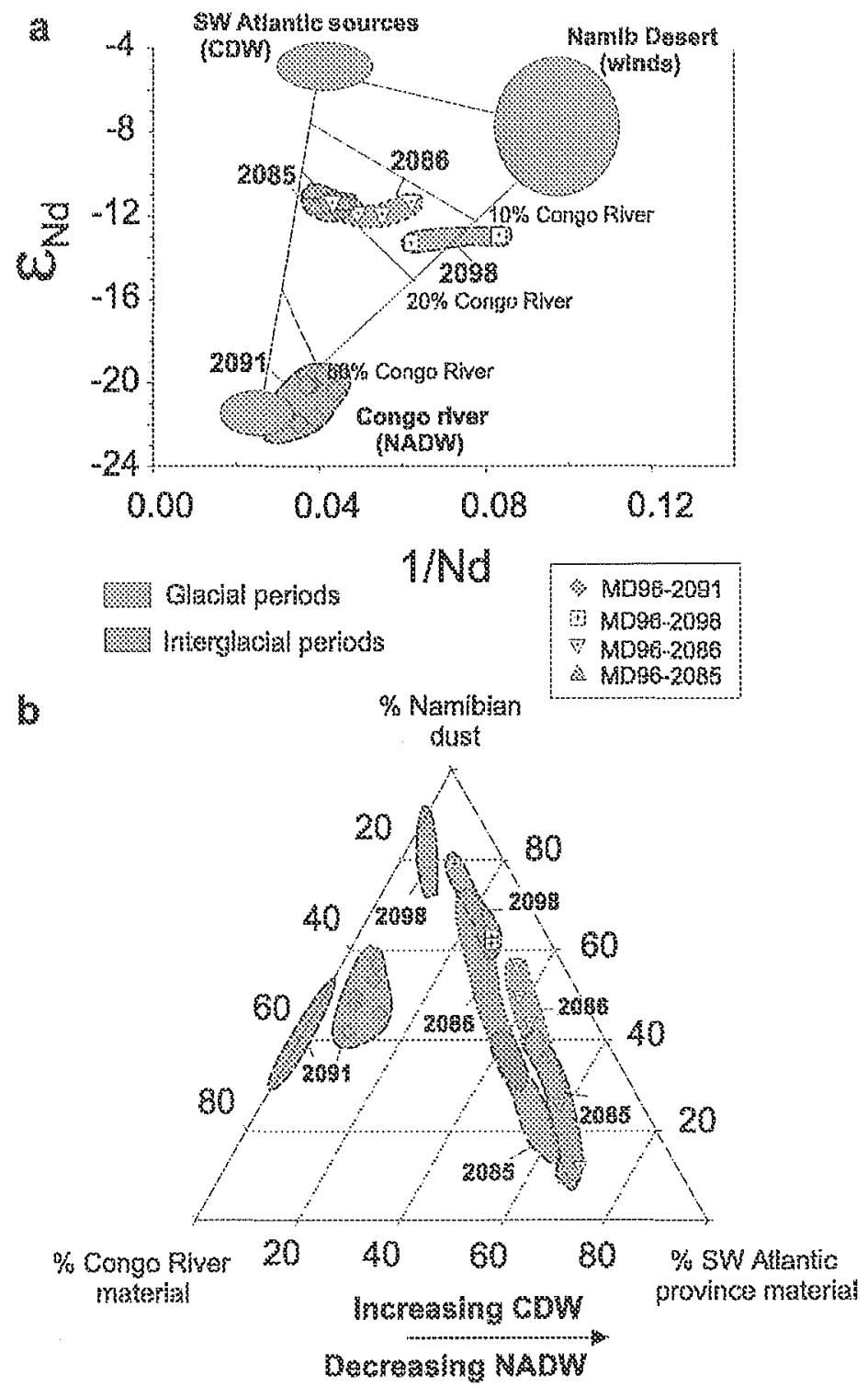

Figure 3. (a) Plot of $\varepsilon_{\mathrm{NA}}$ versus $1 / \mathrm{Nd}$ for detrital fractions from recent (and interghacial) periods. The three potential sources of terrigenous material to the South Allantic are plotted for comparison, with their modes of transport indicated in parentheses. Mixing lines between the three end-members are shown, logether with mixing lines corresponding to sediments which contain 10\%, 20\% and 50\% Congo River clays. Nd concentrations and isotopic data for these end-members are from the literature (see Table 2). (b) Temary diagram showing the relative percentages of detritus from the SW Atantic province, Congo River and Namibian dust in our studied samples (relative percentages calculated usiog a simple three-component mixing model).

material, whereas Namibian dust and southwestern Allantic clays more strongly influence Cape Basin sedimentation ( $620 \%$ Congo River clay input). Holocene detrital fractions from MD96-2098, situated near the core of present-day NADW, consist of a mixture of Congo River and Namib Desert material alone. By contrast, core MD96-2086, which samples the boundary between present-day NADW and lower CDW, and core MD96-2085, located further south, are also enriched in material 
Table 2. Three-Component Mixing Model: $\varepsilon N d$ and $[\mathrm{Nd}]$ Values of End-Members ${ }^{\mathrm{a}}$

\begin{tabular}{|c|c|c|}
\hline & $\varepsilon_{\mathrm{Nd}}$ & {$[\mathrm{Nd}] \mathrm{p} p \mathrm{pr}$} \\
\hline $\begin{array}{l}\text { Congo River material } \\
\text { SW Allantic: clay } \\
\text { Namibian dust }\end{array}$ & 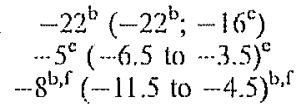 & $\begin{array}{r}40^{\mathrm{d}} \\
25(151028)^{\mathrm{s}} \\
10^{\mathrm{b}}\end{array}$ \\
\hline
\end{tabular}

${ }^{\mathrm{a}} \mathrm{Values}$ between brackets indicate the measured range.

"This work.

${ }^{c}$ Allegre et al. [1996], suspented river loads.

¿ Dupré et al. [1996], suspended river loads.

${ }^{\mathbf{c}}$ Walter ei al [2000], sW Ailantic clay-size detritus.

f Grousset ef al. [1992], Aeolian and sand samples.

transported north by CDW from the SW Atlantic province. Recent detrital fractions in core MD962085, located south of the Namib Desert, plot close to the mixing line between Congo River and SW Atlantic material alone (Figure $3 \mathrm{a}$ ). All these features match the modern-day circulation of deep-water in the Cape Basin remarkably well (Figure 1b). This is important because it provides reassurance that analysis of the $\mathrm{Nd}$ isotopic records preserved down-core within our SE Atlantic marine sediments should yield an accurate record of past variations in deep-water circulation in this region.

\subsection{Detrital Sedimentation in the Glacial SE Atlantic}

[12] Before pursuing any interpretation of the $\mathrm{Nd}$ isotopic record in SE Allantic sediments, however, it is important to consider whether the Nd concentration and isotopic composition of any of the three major potential detrital sources might have fluctuated during the Late Quaternaty. For Nd isotopes, weathering products from various lypes of rock tend to be homogenized thoroughly during both transport - whether by wind or rivers - and deposition - as desert sand or loess [e.g., Asahara et al., 1999]. Therefore, major changes in the $\mathrm{Nd}$ isotopic composition of dust loads from the Namib Desert are not anticipated to have arisen between cold and warm stages. For the Congo River, there is evidence that discharge increased during past interglacials and periods of enhanced monsoon activity [Schneider et al., 1997; Gingele et al., 1998]. However, the Congo River drains an extensive platform, mainly occupied by the Central African Shield, which integrates the lithological and chem- ical diversity of the continental crust. As a consequence, the $\mathrm{Nd}$ isotopic composition of clays delivered by the Congo River has probably remained quite constant over the Late Quaternary. Therefore, although changes in weathering regime in the Congo River catchment basin may have affected the clay mineralogy of the river's suspended load [Gingele et al, 1998], the Sm-Nd isotope systematics of this clay fraction should not be altered significantly. Finally, the Nd isotope ratios of both glacial and interglacial sediments from the Scotia Sea all fall within a linited range $\left(-3.5>\varepsilon_{\mathrm{Nd}}>-6.5\right.$ [Walter ei al., 2000]), suggesting that the isotopic signature of clays transported by CDW has not varied drastically between cold and warm climatic stages, either. In addition, the range of Nd concentrations in terrigenous $\mathrm{SW}$ Atlantic sediments over interglacial/glacial periods is small when compared to variations between our three different end-members [Walter et al., 2000]. This suggest that major changes in the $\mathrm{Nd}$ content of the three end-members are also unlikely to have occurred between glacial and interglacial stages. To a first approximation, we assume therefore that all three "end-member" sources have remained invariant, with respect to $\mathrm{Nd}$ concentrations and isotopes, throughout the glacial and interglacial stages investigated. Next, we investigate past detrital $\varepsilon_{\mathrm{Nd}}$ variations, down-core.

[13] We have calculated percentage contributions of our three "end-member" components (Congo River, SW Atlantic province and Namib Desert) to the detrital phase of all four cores studied (Table 1; Figure 3b). During glacial times, the contribution of Congo River material was reduced in both the Angola Basin (from $\sim 60 \%$ io $\sim 40 \%$ ) and the Cape Basin (from $\sim 20 \%$ to $\sim 10 \%$ ), while the percentage of clays from the southwestern Atlantic increased (Table 1; Figure 3b). This trend is consistent across all four cores, providing further reassurance of the validity of our approach and indicaling that this represents a feature common throughout SE Atlantic sedimentation in the Late Quatemary. The data are consistent with previously reported evidence that the relative influence of NADW was greatly reduced in the South Atlantic during glacial periods, as demonstrated from studies using more 
established paleoceanographic proxies [Charles and Fairbanks, 1992; Bickert and Wefer, 1996; Boyle and Rosenthal, 1996; Dieckmann et al., 1996; Rutberg et al., 2000]. In the next section, we extend this study further and calculate mass accumulation rates for each detrital source, to infer past variations in supply of detrital material associated with CDW and NADW, respectively.

\subsection{Variations in Terrigenous Material Transport by NADW and CDW}

[14] Using the simple three-component mixing calculations employed to construct Figure 3, we have also computed mass accumulation rates (MARs) for Namibian dust; Congo River clays and SW Atlantic province detritus. Calculated mass accumulation rates of Congo River material have remained relatively constant throughout the Late Quaternary (Table 1). For core MD96-2091, with the exception of two marked peaks at $10 \mathrm{kyr}$ and $120 \mathrm{kyr}\left(\sim 2 \mathrm{~g} / \mathrm{cm}^{2} / \mathrm{kyr}\right)$, our calculated MARs for Congo River material have remained guite constant $\left(0.8 \pm 0.5 \mathrm{~g} / \mathrm{cm}^{2} / \mathrm{kyr}\right.$; Figure 4a). Such is also the case for core MD96-2086 (0.3 $\pm 0.2 \mathrm{~g} / \mathrm{cm}^{2} / \mathrm{kyr}$; Figure $4 b)$. This indicates that an efficient transport of this material, by the glacial analog of NADW, must have persisted under glacial conditions; a finding which is in agreement with prior independent ${ }^{231} \mathrm{~Pa} / 230 \mathrm{Th}$ studies [Yu et al, 1996; Marchal et al., 2000].

[15] In contrast, calculated MARs for SW Atlantic detritus in all four cores appear much higher for glacial periods than interglacials. For example, accumulation rates for SW Atlantic fine-grained detritus in core MD96-2086 increased from 0.2 士 $0.2 \mathrm{~g} / \mathrm{cm}^{2} / \mathrm{kyr}$, during interglacial periods, to $1.4 \pm$ $0.2 \mathrm{~g} / \mathrm{cm}^{2} / \mathrm{kyr}$ during glacial times (Figure $4 \mathrm{~b}$ ). With the exception of core MD96-2085, glacial MARs for SW Atlantic material are 300-550\% higher than interglacial values. These variations are always much larger than the relative uncertainly in the calculated MARs for this end-member (ca. $\pm 75 \%)$. To further confirm the validity of our approach, we have also tested the sensitivity of our calculated MARs to changes in $\varepsilon_{\text {Nd }}$ and [Nd] values (within the full range of cited literature values; Table 2) for our three end-ninembers.
An important first result is that, however the $\varepsilon_{\mathrm{Nd}}$ or $[\mathrm{Nd}]$ value used in our calculations is changed, the same interglacial to glacial variations observed in Figure 4 are maintained. By changing the absolute values of $\varepsilon_{\mathrm{Nd}}$ by \pm 2 units, or by changing $[\mathrm{Nd}]$ for any end-member by $\pm 5 \mathrm{ppm}$, a maximum MAR error of $\pm 95 \%$ is calculated. Again, these errors remain small when compared to the 300 $550 \%$ MAR enrichments observed in glacial vs. interglacial periods, further confirming the validity of our conclusion: namely that mass accumulation of CDW transported material has been significantly greater during glacial rather than interglacial periods.

[16] Two mechanisms could account for the changes in terrigenous input observed: (1) a source effect, i.e., a change in the amount of material transported by each of NADW or CDW, due to variations in the Congo River discharge, for example; (2) a transport effect, i.e., a change in the deepwater masses, such as a weakening or strengthening of NADW and/or CDW. Below, we investigate to what extent either or both of these effects could account for the observed changes in temigenous input to our Late Quaternary sediments.

[17] Core MD96-2091, in the Angola Basin, was raised from close to the mouth of the Congo River and, therefore, is probably more sensitive to direct changes in Congo River discharge rather than variations in NADW flow. This is confirmed, apparently, by the strong increases in mass accumulation rate of Congo River material observed at $10 \mathrm{kyr}$ and $120 \mathrm{kyr}$ (Figure 4a), coincident with periods of enhanced monsoon activity (i.e., enlanced chemical weathering) both within the Holocene and during MIS 5 [Schneider et al., 1997]. No similarly marked MAR increases are observed for Congo River clays in the Cape Basin cores (Table 1; Figure 4b), suggesting that these variations in Congo River input must have been attenuated strongly, further south, away from the mouth of the river.

[18] In the Southern Ocean, previous studies of deep-sea sediment cores have routinely shown that accumulation rates of terrigenous material increased significantly during glacial periods 


\section{a MD96-2091 (Ango\}: Basim)}

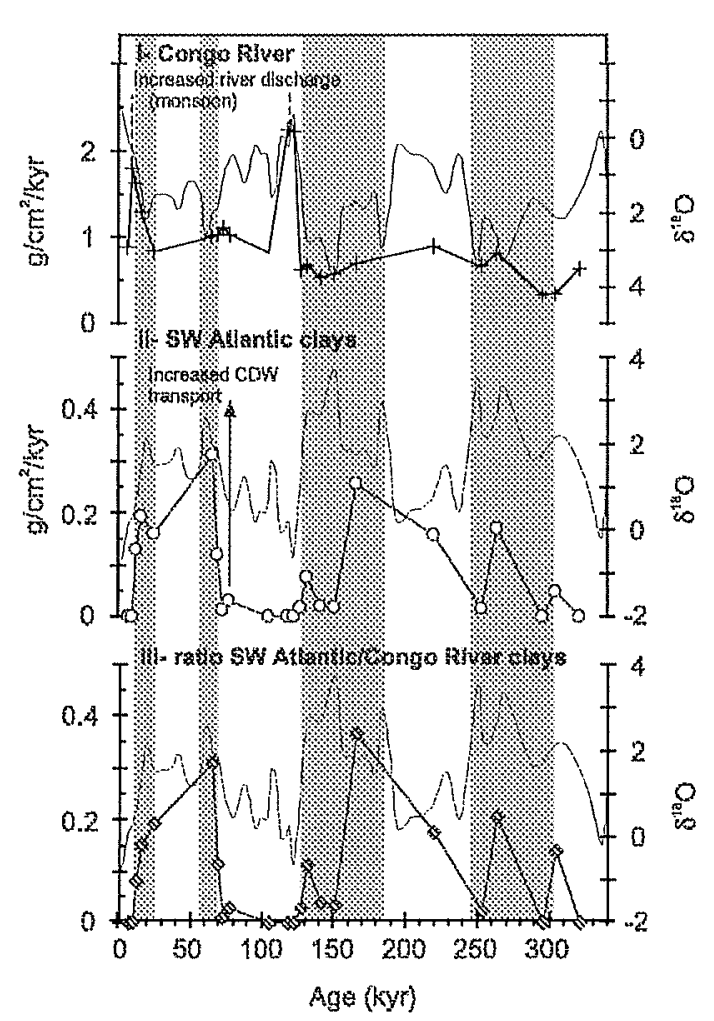

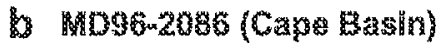

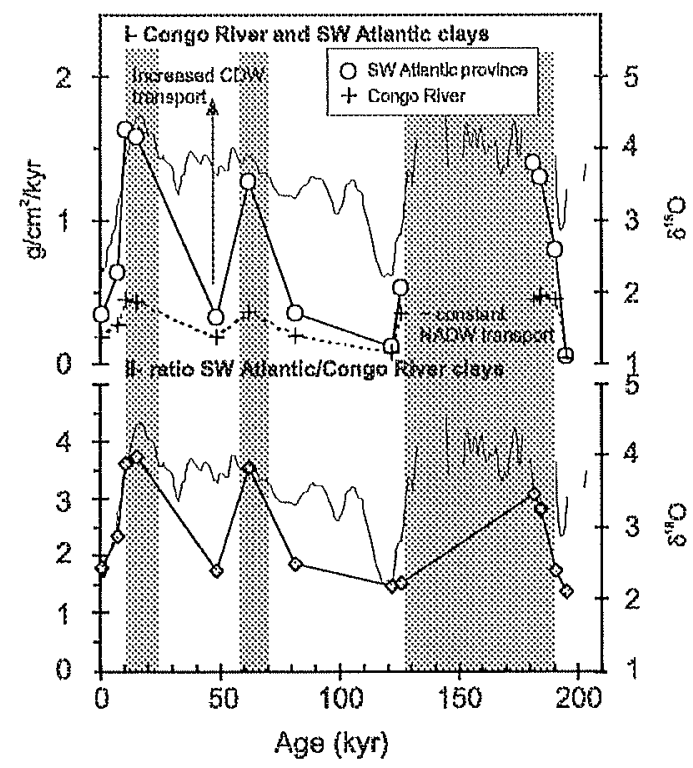

Figure 4. Accumulation rates of Congo River and southwestern Atlantic material, respectively, versus age in (a) core MD96-2091 (Angola Basin) and (b) MD96-2086 (Cape Basin). The $\delta^{18} \mathrm{O}$ climatic signal is shown for comparison. Glacial periods are represented by shaded areas. In core MD96-2091, accumulation of Congo River material was higher during periods of enhanced monsoon activity (10 and $120 \mathrm{kyr}$ [Schneider et al., 1997]) but remained relatively constant throughout the Late Quatemary. Accumulation of SW Atlantic material increased greatly during glacial periods. The ratio SW Atlantic/Congo River clays is high during all glacial periods and can be interpreted as a decrease in the relative influence of NADW (see text for discussion).

[e.g., Dieckmann et al., 1996; Walter et al., 2000; Bareille et al., 1994]. These greater MARs result, primarily, from intensified erosion of the southern American shelf [Walter et al., 2000] coupled with more intensive supply of glaciogenic detritus to the open ocean [Kanfoush et al, 2000]. Compared to those sources, any enhanced input of windblown particles from the southeastern American continent is considered to be relatively minor [Walter et al., 2000]. Therefore, the higher MARs of SW Atlantic material calculated for our SE Allantic sediment cores (Table 1; Figure 4) could derive, in part, from enhanced glacial inputs of detritus to the Southern Ocean, yielding an. increased concentration of suspended material, per unit volume, transported northward by glacial Circumpolar Deep Water.

[19] Simultaneously, however, changes in the deepwater circulation could also account for the varying mass accumulation rates of SW Atlantic detritus and Congo River clays that we have calculated. During glacial stages, the fraction of detritus delivered by CDW to core MD96-2098 (close to the core of modern NADW; $\sim 20 \%$ SW Atlantic clays) was still lower than that delivered to (deeper) core MD96-2086 ( 30-70\%; Figures 16 and 3b). This is consistent with previous studies [Sarnithein et al., 1994; Oppo and Horovitz, 2000] and indicates that stratification of the South Atlantic water column, 
similar to the present-day (Figure 1b), must still have been present during the last glacial maximum. In addition, however, the signilicant increases in accumulation rates for SW Atlantic material during the last glacial maximum provide clear evidence that transport of these sediments to the SE Atlantic by CDW must have been significantly enhanced at that time. This can be observed particularly clearly in the ratios of SW Atlantic:Congo mass accumulation rates which increase systematically from interglacial to glacial periods (Table 1; Figure 4b). One explanation for these enhanced SW Atlantic detritus MARs could be that CDW flow increased during glacial periods.

[20] Certainly, previous studies using the deposition rates of highly particle reactive ${ }^{230} \mathrm{Th}$ have shown that sediment redistribution by bottom currents has been a widespread phenomenon in the Southern Ocean [e.g., Francois et al., 1993, 1997; Kumar et al., 1995; Frank et al., 1996, 1999; Dezileau et al., 2000]. More specifically, in the eastern Atlantic sector of the Southern Ocean, glacial sediment focusing was generally higher than during interglacial periods, indicating a change in the bottomwater flow at that time [Frank et al., 1996, 1999]. That independent ${ }^{230} \mathrm{Th}$ evidence for a change in the botom-water flow, taken together with our calculations of enhanced glacial SW Atlantic detritus accumulation would be entirely consistent with our hypothesis that the northward flow of CDW increased during glacial periods. Finally, we note that, during glacial periods, even core 2091 in the deep Angola Basin, north of the Walvis Ridge appears to have received SW Atlantic province material (Figures 2 and $3 \mathrm{~b}$ ). This, again, would be consistent with overspill of a more intense notthward flow of glacial CDW.

\section{Conclusions}

[21] Analysis of the Nd isotopic composition of detrital fractions in SE Atlantic marje sediments has provided a novel approach for studying the behaviour of each of NADW and CDW, independently, throughout the Late Quaternary. Our data accurately reproduce the complex modern-day hydrography of the SE Atlantic Ocean and provide an independent confirmation of the relative variations in NADW and CDW at the Last Glacial Maximum.

[22] Ymportantly, and in agreement with ${ }^{231} \mathrm{~Pa} /{ }^{230} \mathrm{~T}^{\mathrm{T}} \mathrm{h}$ studies, our new data suggest that an efficient transport of fine-grained material by the glacial analog of NADW, similar to present-day conditions, must have persisted during glacial periods. By contrast, these same data also indicate that the accunulation of SW Atlantic terrigenous material transported northward by CDW increased significantly under glacial conditions. If correct, the data presented here would reconcile tracers of ocean flux (i.e., sedimentary ${ }^{231} \mathrm{~Pa} /{ }^{230} \mathrm{Th}$ ratios), which argue for a continuous export of NADW during glacial periods, with proxies of past seawater composition (e.g., $8^{13} \mathrm{C},{ }^{143} \mathrm{Nd} d^{1 / 44} \mathrm{Nd}$ of Fe-Mn oxide coatings), indicating a strong reduction of the relative NADW influence in the glacial South Atlantic. One possible interpretation of our data would be that the apparent decreased in the influence of NADW during glacial periods could be due, in part, to an increased flow of CDW rather than any major weakening of NADW, itself. What remains to be resolved, however, is to what extent our observations reflect fluctuations in the volume fluxes of each of NADW and CDW or, conversely, are the result of variations in the suspended loads carried by each of these water masses over glacial-interglacial cycles.

\section{Acknowledgments}

[23] We thank Min-Te Chen for providing the stratigraphy for core MD96-2085. Sediment cores were collected during the IMAGES II-NAUSICAA cruise (1996) and we are grateful to the scientists, officers and crew of the R/V Marion-Dufresne. We acknowledge the thoughtful and constnuctive reviews provided by Martin Frank and Derek Vance, together with the Editorial handing of Harry Elderfield, all of which helped to significantly improve the manuscript. Research at the SOC was funded through a NERC Divisional Sudentship (CIB) and the NERC's Core Stralegic Resenrch Program for the Challenger Division (CRG).

\section{References}

Allègre, C. J., B. Dupré, P. Négrel, and J. Gaillardet, Sr-Nd-Pb isotope systematio: in Amazon and Congo River systems: Constraints about erosion processes, Chem. Geol., 131, 93$112,1996$. 
Asahara, Y., T. Tanaka, H. Kamioka, A. Nishimura, and T. Yamazaki, Provenance of the north Pacific sediments and process of source-material thansport as derived from $\mathrm{Rb}-\mathrm{Sr}$ isotopic systematics, Chem. Geol., 158, 271-291, 1999.

Bareille, G., F. E. Grousset, M. Labracherie, L. Labeyrie, and J.-R. Petit, Origin of detrital fluxes in the southeast Indian Ocean during the last climatic cycles, Paleoceanography, 9, $799-819,1994$

Bayon, $\mathrm{G}$., An investigation into $\mathrm{Nd}$ and $\mathrm{Sr}$ isotopes in marine sediments and their application to paleocemography, Ph.D. Thesis, Univ. of Sonthamplon, Hightield, Southampton, 2002

Bayon, G., C. R. German, R. M. Boella, J. A. Milton, R. N. Taylor, and R. W. Nesbitt: Sr and $\mathrm{Nd}$ isotope analyses in paleoceanography: The separation of both detrital and FeMn fractions frorn marine sediments by sequential leaching, Chem. Geol., 187, 179-199, 2002

Bertrand, P. J. Giraudeam, B. Malaze, P. Martinez, M. Gallinari, T. F. Pedersen, C. Piere, and M. Th. Vénec-Peyré, Occurrence of an exceptional carbonate dissolution episode during early glacial isotope stage 6 in the Southeastem Atlantic, Mar Geol., 180, 235-248, 2002a.

Bertrand, P., et al., Organic-rich sediments in ventilated deepsea environments: Clinate, sea-level and trophic changes, J. Geophys. Res., doi:10.1029/200010000327, in press, $2002 \mathrm{~b}$.

Bickert, T., and G. Wefer, Late Quaternary deep water circulation in the South Allantic: Reconstruction from carbonate dissolution and benthic stable isotopes, in The South Athontic: Present and Pesst Circulation, edited by G. Wefer, W. H Berger, C. Siedler, and D. Webb, pp. 599-620, SpringerVerlag. New York, 1996.

Bickert, T., and. G. Wefer, South Atlantic and benthic foraminifer $0^{13} \mathrm{C}$ deviations: implications for reconstructing the Late Qubtemary deep-water circulation, Deep Sea Res. Part II. $46,437-452,1999$.

Biscaye, P. E., Mineralogy and sedimentation of recent deep ser clay in the Atlantic Ocen and adjacent seas and oceans, Geol. Soc. Am. Bull. 76,803-832, 1965

Boyle, F. A., Cammun and $\delta^{13} \mathrm{C}$ paleochemical ocean distribution during the stage 2 glacial maximum, Ann. Rev. Eath Plonet. Sici., 20, 245-287, 1992.

Boyle, E. A., and Y. Rosenthal, Chemical hydrography of the South Atantic during the Last Glacial Maximum: Cd vs. $8^{13} \mathrm{C}$, in The South Atlanic: Present and Past Circulation, edited by G. Wefer, W. H. Berger, G. Siedler, and D. Webb, pp. 423-443, Springer-Verlag, New York, 1996.

Broecker, W. S., The great ocean conveyor, Oceanography, 4 , $79-89,1991$

Broecker, W. S., and G. H. Denton, The role of ocenn-atmosphere reorganizations in glacial cycles, Geochim. Comochim. Acta, 53, 2465-2501, 1989.

Charles, C. D., and R. G. Fairbanks, Evidence form Southem Ocean sediments for the effect of North Atlantic deep-water flux on climate, Nanre, 355, 416-419, 1992

Chen, M-T., Y.-P. Chang, C.-C. Chang, L.W. Wang, C.-H Wang and F.-F. Yu, Latfe Quatemary sea-surface temperature variations in the southeast Atlantic: a planktic fora- minifer faunal record of the past $600,000 \mathrm{yr}$ (IMAGES II MD962085), Mar: Geol., 180, 163 181, 2002.

Dezileau, L., G. Bareille, J. L. Reyss, and F. Lemoine, Evidence for strong sediment redistribution by bottom currents along the southeast Indian ridge, Deep Sea Res. Part I, 47 , $1899-1936,2000$

Dieknann, D., R. Petschick, F. X. Gingele, D. K. Fütterer, A. Abelmann, R. Gersonde, U. Brathauer, and A. Mackensen, Clay mineral fluchutions in the Late Quaternary sediments of the southeastern Atlantic: Implications for past changes of deepwater advection, in The South Atlantic: Present and Past Cinculaiton, edited by G. Wefer, W. H. Berger, G. Siedler, and D. Webb, pp. 621-644, Springer-Verlag, New York, 1996.

Dupré, B., J. Gaillardet, D. Rousseau, and C. J. Allègre, Major and trace elements of river-bome material: The Congo Basin, Geochim. Cosmochim. Acta, 60, 1301-1321, 1996.

Francois, R., M. P. Bacon, M. A. Allabet, and L. D. Labeyrie, Glacial/interglacial changes in sediment rain rate in the $\mathrm{SW}$ Indian sector of Subantarctic waters as recorded by ${ }^{230} \mathrm{Th}$, ${ }^{231} P 1, U$, and $\delta^{15} \mathrm{~N}$, Paleoceanography, 8, 611-629, 1993.

Francois, R., M. A. Altabet, E.-F. Yu, D. Sigman, M. P. Bacon, M. Frank, G. Bohmann, G. Bareille, and L. Labeyrie, Contribution of Southern Ocean surface-water stratification to low atmospheric $\mathrm{CO}_{2}$ concentrations during the last glacial period, Nature, 389, 929-935, 1997.

Frank, M., R. Gersonde, M. Rutgers van der Loeff, G. Kuhn, and A. Mangini, Late Quatemary sediment datiog and quantification of lateral sedinent redistribution applying ${ }^{230} \mathrm{Th}_{\mathrm{ex}}$ : A study from the eastam Atlantic sector of the Southern Ocean, Geol. Nundsch., 85, 554-566, 1996

Frank, M., R. Gersonde, and A. Mangini, Sediment redistribution, ${ }^{230} \mathrm{Th}_{\mathrm{cx}}$-nomalization and implications for the reconstruction of particle flux and export paleoproductivity, in $U_{S E}$ of Proxies in Paleoceanography: Examples from the South Atlantic, edited by G. Fischer and G. Wefer, pp. 409-426. Springer-Verlag, New York, 1999.

Gingele, F. X., and G. Schmield, Comparison of independent proxies in the reconstruction of deep-water circulation in the south-east Atlantic off Namibia, S. Afr. I. Mar: Sci, 21, 181 $190,1999$.

Gingele, F. X., P. M. Müller, and R. R. Solneider, Orbital forcing of freshwater input in the Zaire Fan area - clay mineral evidence from the last $200 \mathrm{kyx}$, Palacogeogr: $\mathrm{Pa}$ lateoclimatol. Palateocol., 122, 77-87, 1998.

Grousset, F. E., P. E. Biscaye. A. Zindler, J. Prospero, and R. Chester, Neodyminm isotopes as tracers in roarine sedments and aerosols: Worth Atlantic, Earth. Planet. Sci. Leil., 87, 367-378, 1988

Grousset, F. E., P. E. Biscaye, M. Revel, J.-R. Petif, K. Pye, S. Joussaume, and J. Jouzel, Antarctic (Dome C) ice-core dust at 18 k.y. B.P.: Isotopic constraints on origius, Earth. Plant. Sci. Lett., 111, 1750-1782, 1992.

Hemming, S. R., P. E. Biscaye, W. S. Broecket, N. G. Hemming. M. Klas, and J. Hajdas, Provenance change coupled with increased clay flux during deglacial times in the western equatorial Allantic, Palacogeog. Falaeoclimatol. Palaeoecol., 142, 217-230, 1998 
Innocent, C., N. Fagel, R. K. Stevenson, and C. Hillaire-Marcel, Sm-Nd signature of modem and late Quaternary sediments from the northwest North Atlantic: Implications for deep curren changes since the last glacial maximum, Earth. Planet. Sci. Lett., 146, 607-625, 1997.

Jones, C. E. A. N. Halliday, D. K. Rea, and R. M. Owen, Neodymium isotopic variations in North Pacitic modern silicate sediment and the insignificance of detrital REE contributions to seawater, Earth. Planet. Sci. Lett., 127, 55-66, 1994.

Kanfoush, S. L., D. A. Hodefl, C. D. Charles, T. P. Guilderson, P. G. Mortyn, and U. S. Ninnemann, Millemnial-scale instability of the Antarctic Ice Sheet during the last glaciation, Science, 28s, 1815-1819, 2000.

Kuhn, G., and B. Diekmann, Late Quatemary variability of ocean circulation in the sontheastem Sonth Atlantic inferred from the terrigenous sediment record of a drift deposit in the southern Cape Basin (ODP Site 1089), Palaeogeog. Palacoclimatol. Palaeoecol, 182, 287-303, 2002.

Kunar, N., R. F. Anderson, R. A. Mortlock, P. N. Froelich, P. W. Kubik, B. Dittrich-Hannen, and M. Suter, Increased biological productivity and export production in the glacial Southern Ocean, Nature, 378, 675-680, 1995.

Lea, D. W., and E. A. Boyle, Foraminiferal reconstruction of barium distributions in water masses of the glacial oceans, Paleocennography, 5, 719-742, 1990.

Mackensen, A., H.-W. Hubberten, T. Bickert, G. Fischer, and D. K. Futterer, The $\delta^{13} \mathrm{C}$ in benthic foraminiferal tests of Fontbotia wuellerstorfi (Schwager) relative to the $8^{13} \mathrm{C}$ of dissolved inorganic carbon in Southen Ocean deep water: Implications for ylacial ocean circulation models, Paleoceanography, 8, 587-610, 1993

Marchal, O., R. Francois, T. F. Stocker, and F. Joos, Ocean thernohaline circulation and sedimentary ${ }^{231} \mathrm{~Pa}^{230} \mathrm{Th}$ ratio, Paleocemography, 15, 625-641, 2000.

Martinson, D. G., N. G. Pisias, J. D. Hays, I. Imbrie, T. C. Moore, and N. J. Shackleton, Age dating and the orbital theory of the ice ages: Development of a high resolution 0 to 300,000 year chronostratigraphy, Quat. Res., 27, 1-29, 1987.

McCorkle, D. C., Evidence of a dissolution effect on benthic foraminiteral shell cherijstry: ${ }^{13} \mathrm{C}, \mathrm{Cd} / \mathrm{Ca}, \mathrm{Ba} / \mathrm{Ca}$ and $\mathrm{S} / \mathrm{Ca}$ results from the Ontong Java Plaieau, Paleoceanography, 10, $699-714,1995$.
McCulloch, MI. T., and G. J. Wasserburg, Sm-Nd and Rb-Sr chronology of continental crust formation, Science, 200, $1003-1011,1978$.

Nakia, S., A. N. Halliday, and D. K. Rea, Provenance of dust in the Pacific Ocean, Earth Planet. Sci. Lett. 119, 143-157, 1993.

Oppo, D. W., and M. Horowitz, Glacial deep water geometry: South Atlantic benthic foraminiferal $\mathrm{Cd} / \mathrm{Ca}$ and $\delta^{13} \mathrm{C}$ evidence, Faleocermography, 15, 147-160, 2000.

Petschick, R., G. Kuhm, and F. X. Gingele, Clay mineral distribution in surface sediments of the South Atlantic - sources, transport and relation to ocenography, Mar: Geol., 130 , $203-229,1996$.

Reid, J. L., On the geostrophic circualtion of the South Atlantic Ocean: Flow patterns, tracers, transports, Progress. Oceuitogr., 23, 149-244, 1989.

Revel, M., M. Cremer, F. E. Grousset, and L. Labeyrie, Grainsize and Sr-Nd isotopes as tracer of paleo-botton current strength, Northeast Atlantic Oceall, Mar: Geol., 131, 233249,1996

Rutherg, R. L., S. R. Hemming; and S. L. Goldstein, Reduced North Atlantic Deep Water flux to the glacial Southern Ocean infecred from neodymium isolope ratios, Nature, $405,935-938,2000$.

Sarnthein, M., K. Winn, S. J. A. Jung, J.C. Duplessy, L. Labeyrie, H. Erlenkeuser, and G. Ganssen, Changes in east Atlantic deepwater circulation over the last 30,000 years: Eight time slice reconstructions, Paleoceanography, 9, 209-267, 1994.

Schneider, R. R. B. Price, P. J. Mueller, D. Kroon, and I. Alexander, Monsoon related variations in Zaire (Congo) sediment load and influence of fluvial silicate supply on marine productivity in the east equatorial Atlantic during the last 200,000 years, Paleocemography, 12, 463-481, 1997.

Walter, H.-l., E. Hegner, B. Diekmam, G. Kuhn, and M. M. Rutgers van der Loeff, Provenance and transport of terrigenous sediment in the South Atlantic Ocean and their relations to glacial and interglacial cycles: $\mathrm{Nd}$ and $\mathrm{Sr}$ isotopic evidence, Geocinim. Cosmochim. Acta, 64, 3813-3827, 2000.

Y. E.F., R. Francois, and M. P. Bacom, Similar rates of moden aud glacial ocean thennohaline circulation inferred from radichehemical data, Nettue, 379, 689-694, 1996. 